\title{
TINDAK TUTUR DALAM TRADISI MENGKET RUMAH MBARU MASYARAKAT KARO
}

\author{
Alemina Br Perangin-angin \\ Fakultas Ilmu Budaya, Universitas Sumatera Utara \\ aleminaperanginangin@gmail.com
}

\begin{abstract}
Abstrak
Penelitian ini berhubungan dengan penggunaan tindak tutur ilokusi yang terdapat dalam tradisi Mengket rumah mbaru pada Masyarakat Karo. Tujuan penelitian ini untuk mengetahui jenis tindak tutur ilokusi apa yang terdapat pada tradisi mengket rumah mbaru, bagaimana makna juga cara penyampaianya oleh pihak kalimbubu, anak beru dan senina. Untuk mengungkapkan fenomena bahasa pada tradisi mengket rumah mbaru, peneliti menggunakan metode descriptive kualitatif, dengan menguraikan, memaparkan objek kajian yang didiskusikan. Dari data yang direprentasikan ditemukan bahwa tindak tutur ilokusi yang digunakan oleh anak beru adalah direktif, kalimbubu tindak tutur ilokusi ekspresif,begitu halnya dengan pihak senina merupakan bentuk ilokusi ekspresif.Cara menyampaikan tuturan yang sopan dengan menggunakan pola pronomina persona ditambah kata kita, tuturan juga dianggap sopan jika disampaikan dengan menggunakan perumpamaan.
\end{abstract}

Kata kunci: mengket rumah mbaru, tindak tutur, ilokusi

\begin{abstract}
Abstrack
This research dealing with the using of speech act of illocution found out in Mengket rumah mbaru or entering a new house tradition in Karonese society. The aim of the research are knowing kind of speech act ilucusion in this tradition, how is the meaning, and how to be said by kalimbubu, anak beru, and senina to know language used in Mengket Rumah Mbaru tradition. This research apply qualitative descriptive method by describe the object discussed. From the data represented it is found out that speech act illucusion performed by anak beru is directive, kalimbubu is expressive, and senina is expressive. The way to express speech act politely using personal pronoun followed by 'kita', the speech is also polite if the sentences using the proverb in the sentences to express the meaning.
\end{abstract}

Keywords: mengket rumah mbaru, speech act, illocusion

\section{PENDAHULUAN}

Komunikasi memiliki peran yang sangat penting dalam interaksi manusia sebagai makluk sosial. Kegiatan tersebut dilakukan bukan hanya sebagai cara bertukar informasi juga sebagai sarana pelekat rasa kekeluargaan, wujut keperdulian juga saling menasihati. Salah satu wujut komunikasi tersebut dapat dilakukan dalam kegiatan adat-istiadat seperti pada tradisi mengket rumah mbaru atau tradisi memasuki rumah baru pada Masyarakat Karo. Tradisi mengket rumah mbaru merupakan suatu bentuk acara syukur kepada Tuhan YME juga penghormatan dan berbagi kebahagiaan kepada kepada kerabat karena keberhasilan seseorang mendirikan rumah baru. Masyarakat Karo memiliki sistem kekerabatan masyarakat dengan nama merga si lima, rakut si telu, tutur si siwah perkadekaden tambah sada. Posisi seseorang sebagai anakberu, kalimbubu, serta senina berbeda dalam peradatan. Hal itu berkaitan dengan posisi seseorang yang menyangkut hak dan kewajiban mereka. Tuturan yang mereka lakukan pada saat acara mengket rumah mbaru 
merupakan hal yang menarik untuk diteliti dari sisi pragmatik. Dalam pelaksanaan tradisi mengket rumah mbaru, cara berkomunikasi yang baik antara anak beru, kalimbubu, dan senina merupakan hal pokok dalam meyelesaikan peradatan. Cara tutur yang salah akan merusak hubungan kekeluargaan juga dapat dianggap sebagai 'orang yang tidak beradat' atau orang yang tidak memiliki sopan santun. Ungkapan tersebut merupakan suatu hal yang sangat kasar jika hal itu sempat terucap oleh orang lain. Cara bertutur seseorang merupakan merupakan cermin bagaimana dia menghormati lawan bicaranya. Penelitian ini menggunakan kajian tindak tutur ilokusi dalam tuturan tradisi mengket rumah mbru yang dituturkan oleh pihak anak beru, kalimbubu dan senina. Tindak tutur atau tindak ujar (speech act) adalah entitas yang bersifat sentral dalam pragmatik. Tindak tutur merupakan dasar bagi analisis topik-topik pragmatik lain seperti praanggapan, prinsip kerja sama, dan prinsip kesantunan. Tindak tutur memiliki bentuk yang bervariasi untuk menyatakan suatu tujuan. Austin (1962) menyebutkan bahwa pada dasarnya pada saat seseorang mengatakan sesuatu, dia juga melakukan sesuatu. Pernyataan tersebut kemudian mendasari lahirnya teori tindak tutur. Jadi dapat disimpulkan bahwa tindak tutur merupakan suatu ujaran yang mengandung tindakan sebagai suatu kesatuan fungsional dalam komunikasi yang mempertimbangkan aspek situasi tutur.

Tindak tutur dan peristiwa tutur sangat erat terkait. Keduanya merupakan dua gejala yang terdapat pada satu proses, yakni proses komunikasi. Peristiwa tutur merupakan peristiwa sosial karena menyangkut pihak-pihak yang bertutur dalam satu situasi dan tempat tertentu. Peristiwa tutur ini pada dasarnya merupakan rangkaian dari sejumlah tindak tutur yang terorganisasikan untuk mencapai suatu tujuan. Dengan demikian, tindak tutur selalu berada dalam peristiwa tutur. Kalau peristiwa tutur merupakan gejala sosial seperti disebut di atas, maka tindak tutur merupakan gejala individual, bersifat psikologis, dan keberlangsungannya ditentukan oleh kemampuan bahasa si penutur dalam menghadapi situasi tertentu. Kalau dalam peristiwa tutur lebih dilihat pada tujuan peristiwanya, tetapi dalam tindak tutur lebih dilihat pada makna atau arti tindakan dalam tuturannya. Jadi dapat disimpulkan bahwa tindak tutur merupakan suatu ujaran yang mengandung tindakan sebagai suatu kesatuan fungsional dalam komunikasi yang mempertimbangkan aspek situasi tutur.

Searle (dalam Rahardi, 2005:36) menggolongkan tindak tutur ilokusi itu kedalam lima macam bentuk tuturan yang masing-masing memiliki fungsi komunikatif. Kelima macam bentuk tuturan yang menunjukkan fungsi itu dapat dirangkum sebagai berikut:

1. Asertif (Assertives) yakni bentuk tuturan yang mengikat penutur pada kebenaran proposisi yang diungkapkan, misalnya menyatakan (stating), menyarankan (suggesting), menbual (boasting), mengeluh (complaining), dan mengklaim (claiming).

2. Direktif (Directives), adalah bentuk tuturan yang dimaksudkan penuturannya untuk membuat pengaruh agar si mitra tutur melakukan tindakan, misalnya, memesan (orderin), memerintah (commanding), memohon (requesting), menasehati (advising), dan merekomendasi (recommending).

3. Ekspresif (Expressives) adalah bentuk tuturan yang berfungsi untuk menyatakan atau menunjukkan sikap psikologis penutur terhadap suatu keadaan, misalnya berterima kasih (thanking), memberi selamat (congratulating), meminta maaf (pardoning), menyalahkan (blambing), 
memuji (praising), berbelasungkawa (condoling).

4. Komisif (Commissives), yakni bentuk tuturan yang berfungsi untuk menyatakan janji atau penawaran, misalnya berjanji (promising), bersumpah (vowing), dan menawarkan sesuatu (offering)

5. Deklarasi (Declarations), yaitu bentuk tuturan yang menghubungkan isi tuturan dengan kenyataan, misalnya berpasrah (resigning), memecat (dismissing), menbaptis (chistening), memberi nama (naming), mengangkat (appointing), mengucilkan (excommicating), dan menghukum (sentencing).

\section{METODE}

Penelitian dilakukan di Kabanjahe Kabupaten Karo, secara langsung terlibat dalam acara mengket rumah mbaru untuk mendapatkan tindak tutur yang diujarkan oleh pihak kalimbubu, senina dan anak beru. Metode deskriptif kualitatif digunakan dalam penelitian ini. Data-data dikumpulkan dengan mengadakan wawancara langsung dengan pelaku, melakukan observasi langsung, mendokumentasikan dengan alat perekam audio video juga dibantu dari berbagai refrensi. Data-data yang dikumpulkan dirangkum dengan mengumpulkan halhal pokok yang yang berakitan dengan objek yang akan diteliti dan menyisihkan data-data yang tidak sesuai, menyajikan data, dan menarik kesimpulan Data-data observasi lalu ditranskrip untuk menganalisis bentuk, fungsi dan jenis tindak tutur yang digunakan oleh pihak anak beru, kalimbubu dan senin.

\section{HASIL DAN PEMBAHASAN}

Berikut data yang diperoleh dari lapangan yang dibahas dibagi menjadi tiga bagian, yaitu tuturan yang diucapkan oleh pihak anakberu, kalimbubu, dan senina. Tindak tutur yang dilakukan oleh anakberu;
Tuturan : Man banta kerina, enggo baci sipersikap perberkatan ta?

(Kepada kita semua, sudah bisakah kita mempersiapkan keberangkatan kita?/ tindak tutur direktif memberi aba-aba)

Lit denga nge gia si tading ras si lupa?

(Masih adakah sesuatu yang tertinggal?/ tindak tutur direktif memberi aba-aba)

Adi la na lit, ras-ras berkat kita kerina, sibenaken dage wari si mehuli enda, ngelakonken kerja nta enda

(Kalau tidak ada lagi yang perlu dipersiapkan, kita berangka bersamasama, kita mulailah hari yang baik ini, untuk melaksanakan acara kita ini/ tindak tutur direktif - memberi aba-aba)

Konteks : Pihak protokol dari anak beru memberikan aba-aba untuk bersiapsiap kepada seluruh anak beru, kalimbubu, senina juga tuan rumah berangkat menuju rumah baru.

Jenis tuturan: Tindak tutur direktif merupakan bentuk tindak tutur yang bermaksut agar mitra tutur melakukan tindakan. Pada tuturan ini anakberu menggunakan pronomina 'man banta kerina' untuk kita semua' merupakan bentuk sopan-santun yang ditujukan kepada semua yang orang-orang yang berada di lokasi tersebut tanpa terkecuali, tanpa dibeda-bedakan ikut serta dilibatkan. Penggunaan pronomina persona kata 'kita' salah satu bentuk sopan santun berkomunikasi oleh pihak anakberu. Begitu juga pemilihan pronomina kamu 'kam, engko' adalam bahasa Karo memiliki tingkat kesopana yang sangat berbeda, kata 'kam' dianggap sopan. Hal itu ditujukan kepada orang yang lebih tua, atau orang yang sebaya atau lebih muda sebagai 
cara menghormati mereka. Sementara kata 'engko' dianggap kasar dan tidak sopan digunakan dalam tuturan, kecuali ditujukan kepada teman sebaya menunjukkan keakraban tanpa memandang usia atau status sosial, atau pronomina persona yang digunakan untuk orang-orang yang lebih muda.

Tuturan: Man kam kalimbubu kami ruh kam ku jenda, enda kalibubu ndu enggo persikapna amak bentar man kam. Ras kam kalimbubu singosei reh kam ku jenda gelah sibenaken ngampeken ose kalimbubu ta enda

(Untuk kalian kalimbubu kami, datanglah kemari, bersama dengan anak beru singosei, ini kalimbubu sierkimbang kalian sudah membentangkan tikar untuk tempat duduk kalian. Untuk kalian kalimbubu singosei kami, datanglah kemari, agar kita melaksankan pememberian ose kalimbubu kita ini

Konteks: Anakberu menyuruh pihak pemilik pesta untuk datang menuju tikar pandan putih yang telah disediakan oleh kalimbubu si erkimbang atau kalimbubu yang bertugas membentangkan tikar utuk tuan rumah, juga menyuruh kalimbubu singosei atau kalimbubu yang bertugas memberikan ose atau pakaian adat lengkap kepada pemilik pesta juga agar datang mendekat menuju tikar pandan putih yang telah disediakan agar peletakan pakaian adat untuk tuan rumah dapat segera dilaksanakan.

Jenis tuturan: Tindak tutur direktif merupakan bentuk tindak tutur yang bermaksut agar mitra tutur melakukan tindakan. Penggunaan pronomina 'kalimbubu kami ' merupakan salah satu bentuk tindak tutur yang sangat sopan pada masyarakat Karo. Hal tersebuat merupakan wujud rasa saling memiliki, tanpa ada rasa membeda-bedakan.

\section{1) Tindak tutur yang dilakukan oleh kalimbubu}

Tuturan: Enda I ampeken kami bulung-bulung ndu alu kemeriahaen ukur, sehat-sehat kam sada jabu, la lit si bangger-bangger, gelemndu ulih ndu latih, ras seh kerina sinisurasurakendu, erpengarak-arak Dibata I tengah jabundu

(Ini kami letakkan bulang-bulang (penutup kepala untuk laki-laki) dengan hati yang senang,semoga sehat-sehat kalian satu rumah, tidak ada yang saki-sakit, dekat rejeki, semua harapan tercapai, Tuhan senantiasa ada ditengah-tengah keluarga kalian.)

\section{Konteks :}

Beka buluh ini adalah kado atau luah kalimbubu si mbaba ose. Acara ini disebuat Ngampeken bulung-bulung. Kalimbubu meletakkan bulang-bulang atau tutup kepala atau ngampeken tudung oleh kalimbubu si mbaba ose. Pemberian luah atau kado berupa beka buluh (kain adat) sebagai bulang-bulang sekarang dilaksankan sebagai simbolisasi, karena tuan rumahlah yang menyediakan perangkat tersebut, namun peletakannya dilaksankan oleh kalimbubu simbaba ose.

Jenis tuturan: Ekpresif adalah bentuk tuturan yang berfungsi untuk menyatakan atau menunjukkan sikap psikologis penutur terhadap suatu keadaan dalam hal ini kalimbubu memberi ucapan selamat, doa dan harapan agar si pemilik rumah diberikan kesehatan, rejeki yang melimpah, juga perlindungan Tuhan YME. Kalimat gelemndu ulih ndu latih memiliki makna kiasan yang berarti rejeki digenggam di tangan, ulih latih (imbalan) bermakna uang tau penghasilan yang dapat ditabung. Penggunaan kiasan atau perumpamaan sebagai salah satu seni bertutur masyarakat Karo, karena penyampaian sesuatu secara langsung dinggap kurang sopan. 
Tuturan: Reh kami kalimbubundu telu sendalanen, emkap kami kalimbubu simanjek daliken, kalimbubu simada dareh ras kalimbubu sierkimbang. Simasuki rumah simbaru enda alu kemeriahen ras arak-arak Tuhan Dibata, maka kami reh majekken dali-kenndu. Enda pajekken kami dalikenndu. Kami kalimbubu simajekken Dali-ken pajekken kami dage dalikenndu makana kam pe singiani rumah enda bebere kami anak beru kami krina ras kempu kami sehatsehat kerina ula bangger-bangger, jadilah rumah enda jadi rumah ingan arih-arih, inganta runggu, inganta meriah ukur, enda $i$ pegara kami api maka meriah ukurta kerina, jenah I ampeken kami ka bengkaun ndu.

(Kami datang kalimbubu tiga serangkai, ya itu kalimbubu simanjek daliken, kalimbubu simada dareh juga kalimbubu sierkimbang hadir di acara ini. Kita memasuki rumah baru dengan hati yang gembira, juga diridhoi Tuhan YME, Maka kami datang untuk membuat/menegakkan daliken (tungku tempat kalian memasak), ini kami mendirikan tungku untuk kalian. Jadi kami kalimbubu simajekken daliken kalain mendirikan tungku tempat kalian untuk memasak agar kalian yang menempati rumah ini (bebere/keponakan kami, anak beru kami) dan cucu kami sehat-sehat semua jauh dari penyakit, jadikanlah rumah ini menjadi rumah tempat berkumpul, tempat untuk bermusyawarah, tempat yang memberikan hati bahagia, ini kami nyalakan api agar kita semua berbahagia , juga diatas api ini kami memasak lauk untuk kalian).

Konteks: kalimbubu simajeken daliken atau pihak kakek dari orang tua tuan rumah,atau kalimbubu yang memiliki kewajiban mendirikan tungku mendirikan tungku untuk tuan rumah sembari mengucapkan kata-kata selamat dan doa agar tuan rumah diberikan limpahan rejeki dan kebahagian mendiami rumah baru mereka.

Jenis tuturan: Ekpresif adalah bentuk tuturan yang berfungsi untuk menyatakan atau menunjukkan sikap psikologis penutur terhadap suatu keadaan dalam hal ini kalimbubu memberi ucapan selamat, doa dan harapan agar si pemilik rumah diberikan kesehatan, rejeki yang melimpah, juga perlindungan Tuhan YME

Tuturan: Jenda pajekken kami menda daliken jenah erpengarapen kerina kam simada kerja enda I pasu-pasu Dibata, I arak-arak na kam kerina gelah sehatsehat, sangap encari, ertuah bayak, ras reh mbue na rejekindu kerina, kelengkelengen I bas jabundu, cawir kam metua kam ras anak-anak sipupus ndu ngiani rumah ndu si mbaru enda. Enda enggo ipajekken kami dalikendu kempu nini bulangna, bere-bere mamana jenah ipegara kami api jenari ampeken kami kudin perdakanen ndu kempu nini bulangna, bere-bere mamana. Enggo tama kami lau meciho, gelah meciho perukeurendu ras kempu kami e kerina I bas mengketi rumah mbar enda. Enda baba kami manok megersing ipankendu sada jabu, gelah dat gegeh si mbaru, lako ngaloken lakon ntah dahin-dahin guna isi jabundu bage pe erlagu mehuli man teman sekelewat geluh ndu."

(kami kalimbubu mendirikan tungku masak dengan harapan agar semua keluarga yang mendiami rumah baru akan diberkati, dilindungi oleh Tuhan YME agar senantiasa diberi kesehatan, diberikan keberuntungan dengan kemudahan dan rejeki yang semakin banyak, diberikaNya kasih sayang di keluarga kalian diberikan umur yang panjang untuk kalian suami istri juga anak-anak untuk menempati rumah ini. Ini kami mendirikan tungku masak/daliken untuk kamu cucu kami 
juga keponakan kami juga kami nyalakan tungku masak kalian dan kami naikkan periuk untuk memasak kalian cucu kami. Kami juga telah mengisinya dengan air yang jernih, agar jernihlah pemikiran kalian suami istri juga cucu-cucu kami melaksanakan acara mengket rumah ini. Ini kami membawa ayam betina, makanlah kalian satu keluarga, agar mendapat memberikan tenaga baru, untuk melaksanakan pekerjaan yang baik yang berguna untuk keluarga kalian agar kalian dapat berbuat baik dengan lingkungan sekitar kalian)

Konteks: Kalimbubu simajekken daliken mendirikan tungku masak untuk pemilik rumah juga memasak air jernih juga memasak ayam, agar seluruh kelurga yang tinggal di rumah baru akan diberikan kekuatan, juga pikiran yang jernih juga dapat melaksanakan hal-hal yang bagus sehingga dapat memberikan kebaikan kepada tetangga.)

Jenis tuturan: Ekpresif adalah bentuk tuturan yang berfungsi untuk menyatakan atau menunjukkan sikap psikologis penutur terhadap suatu keadaan dalam hal ini kalimbubu memberi ucapan selamat, doa dan harapan agar si pemilik rumah kekutan juga pikiran yang jernih

Tuturan: Enda pe kami kalimbubundu I baba kami manok megersing ras naroh manok mulia rikut pe beras meciho gelah piher pertendindu sada jabu ngiani rumah enda. Dingen pulung kerina ulih latih jenah banci rumah enda jadi ingan pulung kami kerina kalimbubu ndu, emaka lalit akap kami salahna, jujungi kami kam alu beres piher. Piher pe batu I lau piheren pertendindu ngiani rumah rumah si mbaru enda !. Rikut ras tinaruh raja manuk raja mulia, gelah termulia kam ngiani rumah si mbaru enda. Pasu-pasu dibata kam kerina, ras rumah enda jadi ingan cio-cio cilinggem, ingan keriahen ukur ras ingan sisampat-sampeten."

("ini kami kalimbubu membawa ayam betina, telur ayam, juga beras putih agar jiwa kalian satu keluarga semakin kuat menempati rumah baru ini. Juga terkumpul semua jerih payah kalian agar rumah ini dapat menjadi tempat berkumpul kami semua kalimbubu kalian, kerena itu tidaklah salah jika kami memberikan berkat dengan meletakkan beras diatas kepala kalian. "Walaupun keras batu di sungai lebih keras lagi jiwa kalian menempati rumah baru ini !". Disertakan naruh manok raja mulia (telur kampung) agar mulia semua orang yang menempati rumah baru ini. Dilindungi Tuhan YME lah kalian semua, juga rumah ini bisa menjadi tempat berteduh, tempat yang memberikan kesenangan hati, juga tempat untuk saling tolong menolong "). Konteks: Kalimbubu simajekken daliken membawakan telur ayam kampung, beras putih, dan meletakkan sejemput beras di atas kepala pemilik rumah agar memiliki kekuatan juga jiwa yang kuat serta rezeki yang yang terkumpul sehingga rumah baru mereka menjadi tempat untuk berkumpul sanak-saudara .

Jenis tuturan : Ekpresif adalah bentuk tuturan yang berfungsi untuk menyatakan atau menunjukkan sikap psikologis penutur terhadap suatu keadaan dalam hal ini kalimbubu memberi ucapan selamat, doa dan harapan agar si pemilik rumah memiliki kekuatan juga jiwa yang kuat serta rezeki yang yang terkumpul sehingga rumah baru mereka menjadi tempat untuk berkumpul sanak-saudara .

\section{2) Tuturann yang dilakukan oleh pihak senina}


Tuturan : Perpulungen simeriah ukur patut sikataken bujur man Dibata ja banci denga kita pulung bas ingan enda alu meriah ras mejuah-juah kita krina. Sinihamati kami kam krina kalimbubu sila ipilihi kami bagepe terus kupuang ni puang kami ija kurang pengalo-ngalo kami ntah penenahken kami surat pendahi kam sekalak-sekalak kurumah ula kel sangkut-sangkut ukur kalimbubu kami labo erkiteken karus kami tapi bage denga kin ngenca kebeluhen kami, daging ngenda nggo metua tapi kebeluhen bagi sikurang denga, bageka pe man senina sembuyak kami ka pe krina ija nggo luangkenndu waktu karna ndahi kami, enda krina melala kel kataken kami bujur man bandu, labo kami beluh ersemulih sembuyak senina kami, tapi erpengarapen kami Dibatalah pagi siersemulih man bandu jenari sikelengi kami kam krina anak beru kami ija nggo la kam erlatih-latih ndahiken dahin kami mulai nari kita mbenaken dahinta endah seh ngasa gundari idah kami maka la kam erlatih-latih tuhu-tuhu dukungndu kami. Bas sadenda melala kel bujur kataken kami nangndangi kam. Si e Dibatalah pagi ersemulih man bandu anak beru kami, endam pengarapen bas kami nari enterem kami jenda peganciganci kami erbelas."

( Perkumpulan yang berbahagia sepantasnya kita mengucapkan syukur kepada Tuhan dimana kita masih bisa berkumpul ditempat ini dengan bersukacita dan mejuah-juah kita semua, yang kami hormati kalimbubu kami semuanya tanpa terkecuali begitupun terus ke puang ni puang kami. Dimana masih terdapat kekurangan kami dalam penyambutan ataupun dalam hal mengundang kami melalui surat ataupun yang kami datangi langsung kerumah. Janganlah sakit hati kalimbubu kami itu bukan unsur kesengajaan tapi memang karna hanya sebatas itulah pengetahuan kami tentang adat hanya tubuh yang sudah tua tapi masih sangat kekurangan pengetahuan, begitupun untuk senina sembuyak kami pun semua dimana kalian telah meluangkan waktu untuk hadir ke acara kita ini,ini pun kami mengucapakan terimakasih banyak untuk kalian, kami tidak sanggup untuk membalasnya kepada sembuyak, senina kami, tapi kami berharap Tuhanlah nanti yang membalas semua kebaikan kalian, untuk semua anak beru yang kami kasihi yang telah sibuk membantu mengerjakan acara kami ini mulai dari awal rencana sampai sekarang kami lihat kalian semua tidak letihletihnya benar-benar dalam hal ini kaian sangat mendukung kami , kami mengucapakn terimakasih banyak karena hal itu. Tuhanlah nanti yang membalas semua kebaikan kalian anak beru kami, inilah harapan dari kami, kami disini banyak nanti kami bergantian memberikan kata sambutan.)

Konteks; pemilik rumah memberikan kata sambutan juga ucapan terima kasih kepada pihak anakberu, kalimbubu juga senina. Juga permintaan maaf jika sambutan mereka tidak berkenan.

Jenis tuturan:. Ekspresif bentuk adalah bentuk tuturan yang berfungsi untuk menyatakan atau menunjukkan sikap psikologis penutur terhadap suatu keadaan dalam hal ini pihak senina memberi ucapan terima kasih karena kerja keras anak beru, kalimbubu, juga sembuyak, senina proses acara dapat berlangsung dengan lancar.

\section{KESIMPULAN}

Jenis tindak tutur ilokusi yang banyak dilakukan oleh pihak anak beru dalah bentuk tindak tutur direktif yaitu bentuk tindak tutur yang bermaksut agar mitra tutur melakukan tindakan karena 
pada acara ini pihak anak beru merupakan pihak yang paling bekerja keras untuk melaksanakan semua proses acara, mulai persiapan sehingga akhir acara. Juga yang memiliki kewajiban untuk memandu acara. Jenis tuturan yang banyak digunakan oleh pihak kalimbubu adalah Ekpresif adalah bentuk tuturan yang berfungsi untuk memberikan selamat, memberikan doa restu. Karena posisi kalimbubu meruapakan yang paling agung pada struktur adat masyarakat karo, karena begitu angungnya sehingga ada istilah mereka dianggap sebagai Dibata sin $i$ idah atau Tuhan yang tampak. Jenis tindak tutur ilokusi yang dominan pada tuturan yang diucapkan oleh pihak senina adalah bentuk ekspresif, sama hal dengan kalimbubu, karena pihak senina merupakan bagian dari tuan rumah, tuturan yang mereka gunakan berisi terima kasih kepada pihak kalimbu atau anak beru yang menyelesaikan acara dari awal hingga akhir, meminta maaf jika sambutan. dari tuan rumah tidak berkenan, juga memuji kerja keras pihak anakberu meyiapkan juga menjalankan acra dari persiapan hingga akhir. Bentuk tuturan yang sopan dalam masyarakat Karo salah satunya dengan pengunaan kata kami diakhir pronomina persona, seperti bere-bere kami, anak kami, kempu kami dsb. Dan yang terakhir dengan menggunakan kalimat yang tidak langsung atau dengan menggunakan ungkapan dinggap sebagai suatu yang sopan.

\section{DAFTAR PUSTAKA}

Arikunto, S. (2003). Prosedur Suatu Pendekatan Praktik. Jakarta: Adi Mahasatnya.

Ginting, E. (1996). Adat Istiadat Mengket Rumah. Kabanjahe: Percetakan Abdi Karya.

Hamid Hasan Lubis, H. (1991). Analisi Wacana Pragmatik. Bandung: Angkasa.
J.L, A. (1955). How To Do Things With Words. London: Oxford.

Prinst, D. (2014). Adat Karo. Medan: Bina Media Printis.

Rahardi, K. (2005). Pragmatik : Kesantunan Imperatif Bahasa Indonesia. Jakarta: Erlangga.

Sugiyono. (2005). Memahami Penelitian Kualitatif. Bandung: CV Al Fabeta. 